\title{
Paracoccidioidomycosis case series with and without central nervous system involvement
}

\author{
Vinicius Sousa Pietra Pedroso ${ }^{[1]}$, Ana Claudia Lyon ${ }^{[1]}$, Stanley Almeida Araújo ${ }^{[1]}$, \\ Juliana Márcia Ribeiro Veloso ${ }^{[1]}$, Enio Roberto Pietra Pedroso ${ }^{[1],[2]}$ and Antônio Lucio Teixeira ${ }^{[1],[2]}$
}

[1]. Programa de Pós-Graduação em Infectologia e Medicina Tropical, Faculdade de Medicina, Universidade Federal de Minas Gerais, Belo Horizonte, MG. [2]. Departamento de Clínica Médica, Faculdade de Medicina, Universidade Federal de Minas Gerais, Belo Horizonte, MG.

\section{ABSTRACT}

Introduction: Paracoccidioidomycosis (PCM) is the most important systemic mycosis in South America. Central nervous system involvement is potentially fatal and can occur in $12.5 \%$ of cases. This paper aims to contribute to the literature describing eight cases of neuroparacoccidioidomycosis (NPMC) and compare their characteristics with patients without neurological involvement, to identify unique characteristics of NPCM. Methods: A cohort of 213 PCM cases was evaluated at the Infectious Diseases Clinic of the University Hospital, Federal University of Minas Gerais, Brazil, from October 1976 to August 2008. Epidemiological, clinical, laboratory, therapeutic and follow-up data were registered. Results: Eight patients presented NPCM. The observed NPCM prevalence was 3.8\%. One patient presented the subacute form of PCM and the other seven presented the chronic form of the disease. The parenchymatous form of NPCM occurred in all patients. $60 \%$ of the patients who proceeded from the north/ northeast region of Minas Gerais State developed NPCM. The neurological involvement of a mother and her son was observed. NPCM patients exhibited demographical and clinical profiles similar to what is described in the literature. When NPCM cases were compared to PCM patients, there were differences in relation to origin and positive PCM family history. Conclusions: The results corroborate the clinical view that the neurological findings are extremely important in the evaluation of PCM patients. Despite the limitations of this study, the differences in relation to patient's origins and family history point to the need of further studies to determine the susceptibility factors involved in the neurological compromise.

Keywords: Paracoccidioidomycosis. Neuroparacoccidioidomycosis. Epidemiology. Case series.

\section{INTRODUCTION}

Paracoccidioidomycosis (PCM), a systemic infection caused by the fungus Paracoccidioides brasiliensis (Pb), is the most important deep mycosis in South America ${ }^{1}$. It can be considered a public health problem due to the elevated social and economic costs borne not only by the active disease, but also by the frequent associated sequelae ${ }^{2}$.

It affects patients of all ages, but is more common among individuals with ages ranging from 30 to 50 years. There are no differences in incidence between genders until puberty; however, in adult life, it becomes more frequent among men, in an 11:1 ratio ${ }^{3}$.

The infection occurs by the inhalation of propagules of the fungus, resulting in a primary pulmonary complex, usually asymptomatic, which tends to resolve spontaneously, leaving residual lesions that may contain viable fungi for years. Nevertheless, in some cases, the primary infection develops, leading to a symptomatic pulmonary disease or spreading to other sites by hematological and/or lymphatic routes, affecting virtually any organ ${ }^{3,4}$. In general, the most affected sites are the lungs, the skin, mucous membranes, lymph nodes and adrenal glands. In the last decades, with the development of new diagnostic methods, especially neuroimaging, it was verified that central nervous system (CNS) involvement is much more common than it was thought to be, taking place in approximately $12.5 \%$ of the case $^{5,6}$ and reaching, in one study, $36 \%$ of them².

Address to: Dr. Antonio Lucio Teixeira. Depto Clínica Médica/FM/UFMG. Av. Alfredo Balena 190, Santa Efigênia, 30130-100 Belo Horizonte, MG, Brasil.

Phone: 5531 3409-2651

e-mail: altexr@gmail.com

Received in 12/03/2012

Accepted in 22/05/2012
Several authors have associated the neurological form of PCM with prolonged clinical course, diffuse involvement and immunosuppression. However, a few works in the literature make comparisons between patients presenting NPCM and patients without neurological involvement. Most of these studies make only diagnostic approaches, comparing the detection capacity of some antigen in the sera of patients with and without neuroparacoccidioidomycosis (NPCM) or evaluating the detection of these markers in the cerebrospinal fluid ${ }^{7-10}$. Therefore, there is a lack of studies that define singular clinical features that could distinguish the development of NPCM.

Thus, the present study reports and analyzes the epidemiological, clinical and therapeutic characteristics of eight NPCM cases assisted at the Infectious Diseases Clinic of the University Hospital of the Federal University of Minas Gerais, Belo Horizonte, Brazil, comparing them to the cases of PCM without neurological involvement assisted at the service.

\section{METHODS}

From October 1976 to August 2008, 213 PCM cases were assisted at the ambulatory. Epidemiological, clinical, laboratory, therapeutic and follow-up data were registered in a database generated by the software SPSS 12.0. The analyses were made with this software using the Chi-square, the Fisher exact tests or Student's t-test. Cases had the diagnosis confirmed by complementary methods (biopsy, immunological assay, culture or direct microscopy of clinical specimens) or by necropsy.

Nine of the 213 cases presented neurological symptoms associated with the disease. However, one of these cases was excluded because the patient missed the follow-up and it was not possible to confirm 
the presence of CNS lesions. The diagnosis of NPCM was made by the presence of typical neuroimaging findings (ring-like contrast enhancement lesions - Figure 1) concomitantly with fungus isolation from other sites (lungs or skin). In three cases, diagnosis was further confirmed with neurosurgical drainage of brain lesions and fungus isolation.

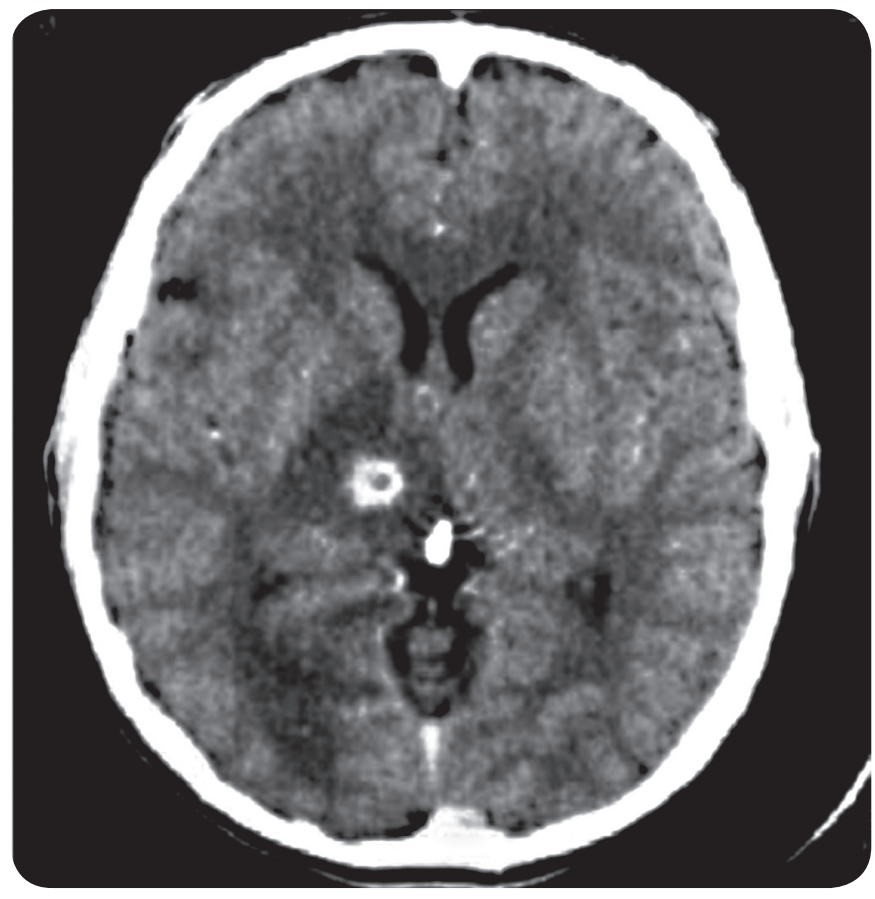

FIGURE 1 - Computed tomographic scan showing the typical ring-like appearance of a lesion located in the right thalamus (case 2).

Source: Infectious Diseases Clinic of the University Hospital of the Federal University of Minas Gerais.

\section{Ethical considerations}

This study was approved by the Universidade Federal de Minas Gerais Ethics Committee for Clinical Research.

\section{RESULTS}

The prevalence of NPCM among the observed population was $3.8 \%$ (95\% confidence interval: 1.7-7.0). Seven patients were male, with mean age of 42 years, ranging from 24 to 61 years. One patient presented the subacute form of PCM and the other seven presented the chronic form of the disease, but all of them exhibited the parenchymatous form of NPCM.

Four patients were rural workers, two were bricklayers, one was a homemaker and there was no occupational information in one case.

Six patients had previous histories of non-neurological PCM and the other two patients had their PCM diagnosis made with the neurological manifestations. The disease was never limited to the CNS and the skin was the most frequently affected site (62.5\%), followed by the lungs and lymph nodes (37.5\%), and by mucous membranes (25\%). Laryngeal and adrenal involvements were also observed. All the cases are summarized in Table 1.

The clinical picture was characterized especially by signs of intracranial hypertension (62.5\% of the cases), and headache was the most common complaint. Motor deficits were observed in $44.4 \%$ of the cases; seizures, sensitive and cognitive deficits were exhibited by $33.3 \%$ of them.

NPCM's mean time to diagnosis, defined as the period between the onset of neurological symptoms until the search for medical attention, was 3.8 months, ranging from one week to one year.

All patients underwent computadorized tomography scanning of the skull. Seventy-five percent of the lesions were located at the supratentorial compartment, while $50 \%$ were infratentorial. In the supratentorial compartment, the frontal lobes were the most affected sites, with $37.5 \%$ of the lesions, followed by the temporal and parietal lobes ( $25 \%$ each) and by the occipital lobes, basal nuclei e thalamus (12.5\% each). In the infratentorial compartment, lesions were restricted to the cerebellum.

All patients were treated with more than one drug and the most used combination was amphotericin B with sulpha, especially the association sulphamethoxazole-trimethoprim $(n=6)$. The azolic agents were commonly used too, especially Ketoconazole $(n=4)$. The mean treatment time was 4.5 years and there were no deaths. Surgical procedures (craniotomy with abscess drainage) were performed in three cases.

Approximately $63 \%$ of the patients developed sequelae in the follow-up: $60 \%$ of them remained with sensitive deficits, $40 \%$ of them, with motor deficits or seizures and $20 \%$ with gait disturbances.

After the characterization of the cases, data from NPCM patients were compared to non-neurological PCM patients.

Demographic profiles from both groups of patients were compared. No statistical difference was observed in gender distribution or age. When considering origin, it was observed that there were $42 \mathrm{PCM}$ patients who came from the same Minas Gerais state's macro regions from which NPCM patients came. This distribution was statistically different in the north/northeast region $(60 \%$ of the patients who proceeded from this region ( $n=5)$ developed NPCM $(n=3), p<0.001$, Fisher exact test). There was also a difference in relation to the cases which came from other Brazilian States (Bahia, Espírito Santo and Pernambuco (24 PCM cases and 3 NPCM cases), p=0.042, Fisher exact test). The two groups had similar occupational distributions.

Clinical aspects were also compared. The mean time course of the disease was 11.4 months among NPCM patients and 13.83 months among PCM patients, without statistical difference. There were no differences related to the diagnosis form either.

Many clinical signals and symptoms exhibited by the patients at the first consultation were registered in the research protocol form. A positive association was observed between the neurological form of the disease and the presence of headache $(p=0.001)$, sweating $(p=0.004)$, seizures $(p=0.006)$, dizziness $(p=0.028)$ and focal deficit $(p=0.011)$.

The frequency of non-neurological affected sites was also compared between the two groups. There was no difference among all the various forms of the disease and the development of NPCM, including the multifocal or disseminated form.

No differences were observed when considering the patients past medical history, intravenous drug use and previous or current tobacco use or alcoholism. However, there was a positive relation between PCM family history and the development of NPCM ( $p=0.014)$.

Finally, no differences related to the relapse of the disease or to the period passed until the relapse could be observed. 
TABLE 1 - Demographic and clinical data exhibited by eight patients with neuroparacoccidioidomycosis assisted at the Infectious Clinic of the University Hospital, Federal University of Minas Gerais, Belo Horizonte, Brazil.

\begin{tabular}{|c|c|c|c|c|c|c|}
\hline Gender & $\begin{array}{c}\text { Age } \\
\text { (years) }\end{array}$ & $\begin{array}{c}\text { Clinical } \\
\text { manifestations }\end{array}$ & $\begin{array}{c}\text { Time to } \\
\text { neurological } \\
\text { diagnosis }\end{array}$ & Lesions & Treatment & Sequelae \\
\hline $\bar{M}$ & 40 & $\begin{array}{l}\text { seizures, speech disturbance, } \\
\text { left facial palsy, left } \\
\text { hemiparesia, hypo/dysesthesia } \\
\text { on the left side of the body and } \\
\text { dismetry }\end{array}$ & 5 months & $\begin{array}{c}\text { frontal lobe } \\
\text { occipital lobe } \\
\text { basal nuclei } \\
\text { thalamus } \\
\end{array}$ & $\begin{array}{c}\text { amphotericin B } \\
\text { SMT-TMP } \\
\text { ketoconazole }\end{array}$ & $\begin{array}{c}\text { motor, } \\
\text { sensitive and } \\
\text { seizures }\end{array}$ \\
\hline M & 24 & $\begin{array}{l}\text { seizures, headache, dizziness, } \\
\text { III right facial nerve paresia, } \\
\text { central right facial palsy, } \\
\text { paraplegia, T7(R) and T9(L) } \\
\text { sensitive levels and } \\
\text { sphincter incontinence }\end{array}$ & 15 days & $\begin{array}{l}\text { several brain } \\
\text { lesions } \\
\text { cerebellum }\end{array}$ & $\begin{array}{l}\text { amphotericin B } \\
\text { SMT-TMP }\end{array}$ & no sequelae \\
\hline M & 30 & $\begin{array}{c}\text { frontal headache, behavioral } \\
\text { disturbance and faints }\end{array}$ & 20 days & $\begin{array}{l}\text { frontal lobe } \\
\text { temporal lobe }\end{array}$ & $\begin{array}{l}\text { amphotericin B } \\
\text { sulphadiazine }\end{array}$ & $\begin{array}{c}\text { no sequelae } \\
\text { (lost follow-up) }\end{array}$ \\
\hline$M$ & 46 & $\begin{array}{l}\text { headache, anterograde } \\
\text { memory impairment, } \\
\text { confusion, dizziness, } \\
\text { visual impairment and right } \\
\text { hemiparesia }\end{array}$ & 1 year & parietal lobe & $\begin{array}{l}\text { amphotericin B } \\
\text { SMT-TMP } \\
\text { ketoconazole } \\
\text { fluconazole } \\
\text { surgical }\end{array}$ & $\begin{array}{l}\text { motor and } \\
\text { sensitive }\end{array}$ \\
\hline M & 51 & $\begin{array}{l}\text { severe headache, vomiting, } \\
\text { fever asthenia and faints }\end{array}$ & 1 week & $\begin{array}{l}\text { parietal lobe } \\
\text { cerebellum }\end{array}$ & $\begin{array}{c}\text { amphotericin B } \\
\text { SMT-TMP } \\
\text { surgical }\end{array}$ & no sequelae \\
\hline
\end{tabular}

M: male. F: female; CT: computadorized tomography; SMT-TMP: sulphamethoxazole-trimethoprim.

\section{DISCUSSION}

This paper draws together information on a cohort of 213 PCM patients admitted from 1976 to 2008 in the Infectious Diseases Clinic of the University Hospital of the Federal University of Minas Gerais, which is a referral center for the treatment of PCM in a notably endemic area for this disease in Brazil. Despite the methodological limitations imposed by the retrospective analysis of data, the great amount of information in this database allows valuable considerations.

The 3.8\% NPCM prevalence found in the observed population is below the $12.5 \%$ mean prevalence described by some Brazilian groups ${ }^{6,11}$. However, it is very close to the $3.8 \%$ prevalence reported by a recent case series report ${ }^{11}$. Beyond that, it must be noted that NCPM prevalence is extremely variable in the literature, ranging from $0 \%$ to $36 \%^{12-15}$. Interestingly, the majority $(75 \%)$ of the cases reported in this work were diagnosed after 1990, especially after the year 2000 , and the adjusted prevalence to this period is raised to $7.7 \%$.
This is in accordance with the growing trend of NPCM diagnosing in the last decades, which could be due to the expansion of modern neuroimaging methods $s^{4,11,16}$.

The majority of NPCM patients presented the chronic form of PCM, which is in accordance with the literature ${ }^{17,18}$. Moreover, all the cases reported exhibited the parenchymatous form, mainly supratentorial. In a recent systematic review, we found that about $98.3 \%$ of NPCM cases corresponded to the chronic form of PCM, with $89.4 \%$ of the cases exhibiting the pseudotumoral or parenchymatous form of NPCM. Approximately $66.8 \%$ of the lesions occurred in the supratentorial compartment, particularly in the frontal and parietal lobes ${ }^{19}$.

Despite the lack of deaths among the cases, morbidity was high. Nearly $63 \%$ of the patients developed some sequel. Furthermore, in patients who did not remain with any sequel, the time course of the neurological disease was never superior to 20 days. Otherwise, amongst patients who did develop sequelae, this period was longer. Hence, this observation alerts to the fact that with early diagnosis and treatment, the morbidity of the disease could be significantly reduced. 
Epidemiological aspects evaluated between groups of patients with NPCM and PCM did not differ in relation with gender, age or occupational distribution, and these were all in accordance with the literature ${ }^{14,20}$. There were no differences related to life habits such as the use of intravenous drug, tobacco or alcohol. Nonetheless, there was a significant difference $(p<0.001)$ associated to the frequency of NPCM cases in patients proceeding from state's of Minas Gerais North/ Northeast region and other states. This finding could simply reflect a bias related to the lack of referral neurology centers in those regions, leading the patients to be referred to the capital. However, it might be interesting to speculate on other possibilities. As a matter-of-fact, $60 \%$ of the cases originated from Minas Gerais' North/Northeast region corresponded to NPCM cases. This region is geographically close to the States of Bahia and Espírito Santo, from where proceeded other two cases. In spite of the small number of patients observed and the limitations of this study, this observation could raise the hypothesis of the presence of different $\mathrm{Pb}$ strains or even Paracoccididoides species in this region which could be more prone to invade the CNS. In fact, there is a trend in the literature to define new Paracoccidioides species, with diverse geographical distributions and possibly different pathogenic patterns ${ }^{21}$.

The analysis of the clinical manifestations showed the obvious but remarkable importance of neurologic signs in the assessment of NPCM patients, especially the presence of headache, seizures and focal deficits. The observation of these complaints in PCM patients should readily evoke the possibility of neurological involvement and neuroimaging methods are important in identifying CNS lesions.

It must be noted that the antimycotic therapy most frequently used in our sample was Sulphamethoxazole-Trimethoprim and amphotericin $\mathrm{B}$, the two drugs of choice in the treatment of $\mathrm{NPCM}^{20}$. Furthermore, imidazole derivatives were commonly used, especially Ketoconazole $(n=4)$. It should be noted that, with the exception of Fluconazole, these drugs have limited penetration in the CNS and questionable usage in NPCM. However, despite this, we observed in a systematic review of the literature that imidazole derivatives are frequently used in the treatment of NPCM, and Ketokonazole, Fluconazole and Itraconazole were used in $8.3 \%, 8.3 \%$ and $3.9 \%$ of the cases, respectively ${ }^{19}$. This could be due to issues of cost and easy access.

Another interesting fact is the association between NPCM and a positive family PCM history. Despite the small number of patients and the resulting statistical limitations, it is worthy of note that we describe the involvement of a mother and her son (cases 1 and 2). The literature reports other cases of NPCM affecting relatives ${ }^{11}$. Some genetic susceptibility factors to PCM development have been described ${ }^{22,23}$, such as the HLA-A9 (related to a unifocal pulmonary chronic form), HLA-B13 and HLA-B40. Nevertheless, these associations were not observed among NPCM patients ${ }^{9}$. Thus, susceptibility mechanisms which lead to CNS infection should depend on the interaction between fungal and host's factors determining the parasite's penetration into the nervous tissue.

Importantly, there were no significant differences related to disease time course between patients with or without neurological infection. This fact suggests that there is not an association between CNS involvement and a longer course of the systemic disease. There were no noticeable differences also regarding the involvement of non-neurological sites between PCM and NPCM patients. In contrast with some works in the literature, there were no differences even in regard to the multifocal form of the disease. As mentioned, it has been suggested that the penetration of the fungus in the CNS could be related with some specific clinical aspects, particularly severe immunosuppression and intense disease dissemination ${ }^{5}$. However, this was not confirmed in our sample. Thus, our data show that the neurological form was not related to dissemination or to a longer course of disease, and that there could be other factors than simply immunosuppression that could be involved in CNS infection, as specific parasite's or host's characteristics.

To conclude, the demographic and clinical data of the eight NPCM cases reported are similar to those generally attributed to this form of the disease by the literature. Early diagnosis and treatment showed to be fundamental. In comparison to patients without CNS involvement, it could be observed the great importance of neurological examination and neuroimaging. The development of NPCM was not related to prolonged disease course or dissemination and the differences regarding family history and origin, even with limitations, could point to the need of further studies in order to determine susceptibility factors involved in the neurological infection.

\section{CONFLICT OF INTEREST}

The authors declare that there is no conflict of interest.

\section{FINANCIAL SUPPORT}

Conselho Nacional de Desenvolvimento Científico e Tecnológico (CNPq).

\section{ABSTRACT IN PORTUGUESE}

\section{Série de casos de paracoccidioidomicose com e sem envolvimento do sistema nervoso central}

Introdução: A paracoccidioidomicose (PCM) é a micose profunda mais importante na América do Sul. O comprometimento do sistema nervoso central é grave e pode ocorrer em $12,5 \%$ dos casos. Este trabalho tem como objetivo descrever oito casos de neuroparacoccidioidomicose (NPMC) e comparar suas características com pacientes sem envolvimento neurológico, a fim de identificar aspectos singulares da NPCM. Métodos: Uma coorte de 213 casos de PCM foi avaliada na Clínica de Doenças Infecciosas do Hospital das Clínicas da Universidade Federal de Minas Gerais, de outubro de 1976 a agosto de 2008. Dados epidemiológicos, clínicos, laboratoriais, terapêuticos e de seguimento foram registrados. Resultados: Oito pacientes apresentaram NPCM. A prevalência de NPCM observada foi de $3,8 \%$. Um paciente apresentou a forma subaguda da PCM e sete apresentaram a forma crônica. Todos os pacientes apresentaram a forma parenquimatosa. Cerca de $60 \%$ dos pacientes provenientes das regiões norte e nordeste de Minas Gerais desenvolveram NPCM. Foi observado o desenvolvimento de NPCM em uma mãe e em seu filho. Os pacientes com NPCM apresentaram perfis demográficos e clínicos similares à descrição da literatura. Quando comparados aos pacientes com PCM, houve diferenças em relação à procedência de tais pacientes e história familiar positiva de PCM. Conclusões: Os resultados confirmam a importância da avaliação neurológica em pacientes com PCM. Apesar das limitações desse trabalho, as diferenças com relação à procedência dos pacientes e à história familiar apontam para a necessidade de mais estudos para investigar a existência de fatores de susceptibilidade envolvidos no desenvolvimento da NPCM.

Palavras-chaves: Paracoccidioidomicose.

Neuroparacoccidioidomicose. Epidemiologia. Série de casos. 


\section{REFERENCES}

1. McEwen JG, Garcia AM, Ortiz BL, Botero S, Restrepo A. In search of the natural habitat of Paracoccidioides brasiliensis. Arch Med Res 1995; 26:305-306.

2. Mendes RP. Paracoccidioidomicose (Blastomicose Sul-Americana). In: Veronesi R, Focaccia R, editors. Tratado de Infectologia. $3^{\text {rd }}$ ed. São Paulo: Atheneu; 2005. p. 1383-1390

3. Shikanai-Yasuda MA, Telles Filho F, Mendes RP, Colombo AL, Moretti ML. Guidelines in paracoccidioidomycosis. Rev Soc Bras Med Trop 2006; 39:297-310.

4. Fagundes-Pereyra WJ, Carvalho GTC, Góes AM, Silva FCL, Sousa AA. Paracoccidioidomicose do sistema nervoso central: análise de 13 casos. Arq Neuropsiquiatr 2006; 64:269-276.

5. Paniago AM, Oliveira PA, Aguiar ES, Aguiar JI, Cunha RV, Leme LM, et al. Neuroparacoccidioidomycosis: analysis of 13 cases observed in an endemic area in Brazil. Trans R Soc Trop Med Hyg 2007; 101:414-420.

6. Hutzler RU, Brussi MLP, Capitani CM, Lima SS. Acometimento neurológico da paracoccidioidomicose, avaliado pela tomografia computadorizada de crânio. São Paulo Med J 1985; 103:243-244.

7. Silva SHM, Colombo AL, Blotta MHSL, Lopes JD, Queiroz-Telles F, Camargo ZP. Detection of circulating gp43 antigen in serum, cerebrospinal fluid and bronchoalveolar lavage fluid of patients with paracoccidioidomycosis. J Clin Microbiol 2003; 41:3675-3680.

8. Silva SHM, Grosso DM, Lopes JD, Colombo AL, Blotta MH, Queiroz-Telles F, et al. Detection of Paracoccidioides brasiliensis gp70 circulating antigen and follow-up of patients undergoing antimycotic therapy. J Clin Microbiol 2004; 42:4480-4486.

9. Almeida SM, Rebelatto CLK, Queiroz-Telles F, Werneck LC. Major histocompatibility complex and central nervous system involvement by paracoccidioidomycosis. J Infect 2005; 51:140-143.

10. Reis BS, Bozzi A, Prado FLS, Pereira MC, Ferreira FE, Godoy P, et al. Membrane and extracellular antigens of Paracoccidioides brasiliensis (Mexo): Identification of a 28-kDa protein suitable for immunodiagnosis of paracoccidioidomycosis. J Immunol Methods 2005; 307:118-126.
11. Almeida SM. Central nervous system paracoccidioidomycosis: an overview. Braz J Infect Dis 2005; 9:126-133.

12. Francesconi F, Silva MT, Costa RL, Francesconi VA, Carregal E, Talhari S, et al. Longterm outcome of neuroparacoccidioidomycosis treatment. Rev Soc Bras Med Trop 2011; 44:22-25.

13. Pereira WC, Raphael A, Sallum J. Lesões neurológicas na blastomicose sulamericana: estudo anatomopatológico de 14 casos. Arq Neuropsiquiatr 1965; 23:95-112.

14. Plá MP, Hartung C, Mendoza P,StukanoffA, Moreno MJ. Neuroparacoccidioidomycosis: case reports and review. Mycopathologia 1994; 127:139-144.

15. Raphael A. Localização nervosa da blastomicose sul-americana. Arq Neuropsiquiatr 1966; 24:69-90.

16. Tristano AG, Chollet ME, Willson M, Perez J, Troccoli M. Central nervous system Paracoccidioidomycosis: case report and review. Invest Clín 2004; 45:277-288.

17. Gasparetto EL, Liu CB, Carvalho Neto A, Rogacheski E. Central nervous system paracoccidioidomycosis: imaging findings in 17 cases. J Comput Assist Tomogr 2003; 27:12-17.

18. Pereira WC, Raphael A, Tenuto RA, Sallum J. Localização encefálica da blastomicose sul-americana: considerações a propósito de 9 casos. Arq Neuropsiquiatr 1965; 23:113-126.

19. Pedroso VS, Vilela M, Pedroso ER, Teixeira AL. Paracoccidioidomycosis compromising the central nervous system: a systematic review of the literature. Rev Soc Bras Med Trop 2009; 42:691-697.

20. Pedroso VSP, Vilela MC, Pedroso ERP, Teixeira AL. Paracoccidioidomicose com comprometimento do sistema nervoso central: revisão de literatura. Rev Bras Neurol 2008; 44:33-40.

21. Teixeira MM, Theodoro RC, Carvalho MJ, Fernandes L, Paes HC, Hahn RC, et al. Phylogenetic analysis reveals a high level of speciation in the Paracoccidioides genus. Mol Phylogenet Evol 2009; 52:273-283.

22. Lacerda GB, Arce-Gomez B, Telles Filho FQ. Increased frequency of HLA-B40 in patients with Paracoccidioidomycosis. J Med Vet Mycol 1988; 26:253-256.

23. Restrepo FM, Restrepo M, Restrepo A. Blood groups and HLA antigens in Paracoccidioidomycosis. Sabouraudia 1983; 21:35-39. 